\title{
Antioxidant activity of Coriandrum sativum and protection against DNA damage and cancer cell migration
}

\author{
Esther LH Tang, Jayakumar Rajarajeswaran, Shin Yee Fung and MS Kanthimathi*
}

\begin{abstract}
Background: Coriandrum sativum is a popular culinary and medicinal herb of the Apiaceae family. Health promoting properties of this herb have been reported in pharmacognostical, phytochemical and pharmacological studies. However, studies on C. sativum have always focused on the aerial parts of the herb and scientific investigation on the root is limited. The aim of this research was to investigate the antioxidant and anticancer activities of $C$. sativum root, leaf and stem, including its effect on cancer cell migration, and its protection against DNA damage, with special focus on the roots.

Methods: Powdered roots, leaves and stems of C. sativum were extracted through sequential extraction using hexane, dichloromethane, ethyl acetate, methanol and water. Total phenolic content, FRAP and DPPH radical scavenging activities were measured. Anti-proliferative activitiy on the breast cancer cell line, MCF-7, was assayed using the MTT assay. Activities of the antioxidant enzymes, catalase, superoxide dismutase, glutathione peroxidase, and of the caspases-3, -8 and -9 were assayed on treatment with the extract. Cell cycle progression was analysed using flow cytometry. The scratch motility assay was used to assess inhibition of MCF-7 cell migration. DNA damage in 3 T3-L1 fibroblasts was evaluated by the comet assay. The components in the extract were identified by HPLC and GC-MS.

Results: The ethyl acetate extract of $C$. sativum roots showed the highest antiproliferative activity on MCF-7 cells $\left(I C_{50}=200.0 \pm 2.6 \mu \mathrm{g} / \mathrm{mL}\right)$ and had the highest phenolic content, FRAP and DPPH scavenging activities among the extracts. C. sativum root inhibited DNA damage and prevented MCF-7 cell migration induced by $\mathrm{H}_{2} \mathrm{O}_{2}$, suggesting its potential in cancer prevention and inhibition of metastasis. The extract exhibited anticancer activity in MCF-7 cells by affecting antioxidant enzymes possibly leading to $\mathrm{H}_{2} \mathrm{O}_{2}$ accumulation, cell cycle arrest at the $\mathrm{G}_{2} / \mathrm{M}$ phase and apoptotic cell death by the death receptor and mitochondrial apoptotic pathways.
\end{abstract}

Conclusions: This study is the first report on the antioxidant and anticancer properties of $C$. sativum root. The herb shows potential in preventing oxidative stress-related diseases and would be useful as supplements used in combination with conventional drugs to enhance the treatment of diseases such as cancer.

Keywords: Coriandrum sativum, Antioxidants, Anticancer activity, MCF-7, Hydrogen peroxide, Caspase, Cell cycle, DNA damage, Cancer cell migration, Comet assay

\footnotetext{
*Correspondence: kanthi@ummc.edu.my

Department of Molecular Medicine, UMCPR (University of Malaya Centre for

Proteomics Research), Faculty of Medicine, University of Malaya, 50603

Kuala Lumpur, Malaysia
} 


\section{Background}

Plants have played a significant role in providing the human race with remedies. At present, phytotherapy is a recognised complementary and alternative medicinal (CAM) therapeutic modality. It is one of the promising fields in health care as supportive medicine in the treatment of diseases like cancer [1].

Reactive oxygen species (ROS), such as hydroxyl radicals and hydrogen peroxide $\left(\mathrm{H}_{2} \mathrm{O}_{2}\right)$, are constantly generated as normal by-products of mitochondrial respiration. An imbalance between the generation of ROS and cellular antioxidant capacity can lead to oxidative stress. Among the pathologies linked to oxidative stress are atherosclerosis, hypertension, diabetes, inflammation, Parkinson's and Alzheimer's diseases, and cancer [2]. The human body has innate defense mechanisms to counter ROS in the form of antioxidant enzymes such as superoxide dismutase (SOD), glutathione peroxidase (GPx) and catalase (CAT). Consumption of dietary plants as food containing phytochemicals with antioxidant properties, such as phenolics and ascorbic acid, can help strengthen the antioxidant balance of the body [3].

$\mathrm{H}_{2} \mathrm{O}_{2}$ is an oxidizing agent that can be converted to reactive hydroxyl radicals and has been associated with DNA damage, mutations and genetic instability, which can lead to cancer development [4]. $\mathrm{H}_{2} \mathrm{O}_{2}$ can increase cancer cell proliferation and migration [5] resulting in metastasis, which is the leading cause of cancer deaths and ineffectiveness of chemotherapeutic drugs. Plant bioactives may act as cancer chemopreventive agents in normal cells by keeping $\mathrm{H}_{2} \mathrm{O}_{2}$ levels within physiological levels, thus preventing DNA damage. At the same time, plant extracts can also act as chemotherapeutic agents by increasing $\mathrm{H}_{2} \mathrm{O}_{2}$ in rapidly dividing cancer cells to levels that cannot be counterbalanced by the cellular antioxidant systems, producing apoptotic cell death [6]. Natural products have been recognized as inducers of apoptosis in tumor cells of human origin [7]. Consequently, considerable attention has been focused towards natural products as the source of new chemotherapeutic and chemopreventive agents.

Coriandrum sativum $L$. is a culinary and medicinal herb of the Apiaceae family commonly known as coriander. The roots and leaves of $C$. sativum are rich with aromatic flavour and are popularly used in soups in Thai and other Asian cooking. Traditionally, the plant parts are used to alleviate spasms, gastric complaints, bronchitis, gout and giddiness [8]. Previous studies on this herb show their various medicinal properties, including antidiabetic, antioxidant, hypocholesterolemic, antihelmintic, antibacterial, hepatoprotective, anticancer and anxiolytic activities $[9,10]$. The phenolic compounds, apigenin, catechin and $p$-coumaric acid, and aliphatic alkenals and alkanals were reported in C. sativum aerial parts [11,12] while linalool, geranyl acetate and petroselinic acid were found in the fruit [13]. Reviews on C. sativum reported various novel pharmacognostical, phytochemical and pharmacological studies carried out on the plant $[9,10]$. However, studies on $C$. sativum have always focused on the aerial parts of the herb $[14,15]$. Investigations on the medicinal properties of C. sativum roots in scientific literature are scanty and limited, to virtually none. Yet, the roots of this plant are often used in cooking and traditional medicine and are thought to contribute to health and protection against the onset of disease. Therefore, it is imperative that studies should be conducted to investigate the unexploited potential of C. sativum roots. The vast health promoting properties associated with the intake of $C$. sativum in the diet further warrant the herb for study. The main aim of this work was to investigate the antioxidant and anticancer activities of C. sativum and its protection against DNA damage in normal cells and MCF-7 cell migration induced by $\mathrm{H}_{2} \mathrm{O}_{2}$ in vitro. This is the first study reporting the antioxidant and anticancer effects of $C$. sativum root extract on the breast cancer cell line, MCF-7.

\section{Methods}

\section{Chemicals}

Analytical grade chemicals were purchased from Fisher Scientific (UK) and Merck (Germany). Dimethyl sulfoxide (DMSO) and $\mathrm{H}_{2} \mathrm{O}_{2}$ were purchased from Univar (Australia). High performance liquid chromatography (HPLC) grade chemicals and standards, gallic acid, quercetin, rutin, colchicine and mitomycin $\mathrm{C}$ were obtained from Sigma Chemical Co. (UK). HPLC grade acetonitrile was purchased from F S Chemicals (India). Ultrapure water used was purified using the Milli-Q-plus filter system by Millipore (USA).

\section{Plant material}

Fresh Coriandrum sativum roots, leaves and stems were purchased from the wet market in Selayang, Kuala Lumpur, Malaysia. The plant was identified by Dr. M. Sugumaran, Institute of Biological Sciences, University of Malaya. A voucher specimen (KLU47742) was deposited in the University of Malaya Herbarium. C. sativum roots were separated from the leaves and stems using a knife. The plant parts were washed under running tap water to remove dirt and soil and finally rinsed with distilled water. The plant parts were freeze-dried, weighed, ground into fine powder and stored at $-20^{\circ} \mathrm{C}$ until extraction.

\section{Preparation of plant extracts}

Powdered roots, leaves and stems of C. sativum were extracted through sequential extraction using hexane, dichloromethane, ethyl acetate, methanol and water. Briefly, powdered roots $(20 \mathrm{~g})$ and powdered leaves and stems $(120 \mathrm{~g})$ were extracted in 100 and $600 \mathrm{ml}$ of hexane 
$(1: 5 \mathrm{w} / \mathrm{v})$, respectively, for $6 \mathrm{~h}$ at $40^{\circ} \mathrm{C}$ on a hotplate with stirring. Extracts were then filtered through filter paper Whatman no. 1 and the resulting plant residues were reextracted twice with fresh hexane. The remaining plant residue was then extracted using dichloromethane, followed by ethyl acetate, methanol and water (three times in each solvent). Each filtrate (except for the aqueous extract) was concentrated to dryness under reduced pressure at $40^{\circ} \mathrm{C}$ using a rotary evaporator. The aqueous extract was concentrated to dryness in a freeze-dryer. The dried extracts were stored at $-20^{\circ} \mathrm{C}$.

For use in cell culture treatment, the dried extracts were dissolved in DMSO and diluted in ultrapure water to obtain stock solutions which were sterile filtered through $0.2 \mu \mathrm{m}$ syringe filters. Stock solutions were diluted in ultrapure water to make appropriate extract concentrations for testing. The final concentration of DMSO in the cell culture reaction mixture was less than $1 \%$. Extracts were kept at $4^{\circ} \mathrm{C}$.

\section{Determination of total phenolic content}

Total phenolic content (TPC) of C. sativum extracts was determined using the Folin-Ciocalteau method [16] with some modifications. Briefly, $500 \mu \mathrm{l}$ of 1:10 FolinCiocalteau phenol reagent was added to $10 \mu \mathrm{l}$ of sample (dissolved in 10\% DMSO), standard or positive control. The mixture was allowed to stand for $5 \mathrm{~min}$ before the addition of $350 \mu \mathrm{l}$ of $10 \%$ sodium carbonate $\left(\mathrm{Na}_{2} \mathrm{CO}_{3}\right)$. The resulting reaction mixture was incubated in the dark at room temperature (RT) for a further $2 \mathrm{~h}$. Absorbance was then measured at $765 \mathrm{~nm}$ using a spectrophotometer. Gallic acid (50-500 mg/l in 10\% DMSO) was used as the standard. Rutin and quercetin were used as positive controls. Results were expressed in milligrams of gallic acid equivalents (GAE) per gram dried extract. All experiments were carried out in triplicate.

\section{Ferric reducing antioxidant power (FRAP) assay}

The antioxidant activity based on the ferric reducing ability of C. sativum extracts was estimated based on the assay by Benzie \& Strain [17] with some modifications. A working reagent was prepared fresh by mixing $10 \mathrm{ml}$ of $300 \mathrm{mM}$ acetate buffer with $1 \mathrm{ml}$ of $10 \mathrm{mM}$ 2,4,6-tripyridyl-s-triazine (TPTZ) in $40 \mathrm{mM}$ of hydrochloric acid $(\mathrm{HCl})$ and $1 \mathrm{ml}$ of $20 \mathrm{mM} \mathrm{FeCl} \cdot 6 \mathrm{H}_{2} \mathrm{O}$. The freshly prepared FRAP reagent was pre-warmed at $37^{\circ} \mathrm{C}$ for $5 \mathrm{~min}$ after which a blank reading was taken at $595 \mathrm{~nm}$ using a plate reader. Subsequently, $3 \mu \mathrm{l}$ of sample, standard or positive control (each dissolved in 10\% DMSO) and $9 \mu \mathrm{l}$ of water was added to $90 \mu \mathrm{l}$ of the FRAP reagent. Absorbance readings were measured instantly upon addition of the FRAP reagent and again at $4 \mathrm{~min}$ after the start of the reaction. The change in absorbance in the 4 min reaction was calculated by comparison to the absorbance changes of $\mathrm{FeSO}_{4} .7 \mathrm{H}_{2} \mathrm{O}$ against a standard curve $(100-1000 \mu \mathrm{M})$ tested in parallel. Rutin and quercetin were used as positive controls. Results were expressed as mmol ferric reducing activity of the extracts per gram of dried extract. All experiments were carried out in triplicate.

\section{DPPH radical scavenging activity}

Radical scavenging activities of $C$. sativum sequential extracts were determined by 1,1-diphenyl-2-picrylhydrazyl (DPPH) radical scavenging assay [18] with some modifications. The extract $(20 \mu \mathrm{l})$ was added to $120 \mu \mathrm{l}$ of $0.04 \mathrm{mg} / \mathrm{ml} \mathrm{DPPH}$ solution in methanol. The extracts tested ranged from $0-5000 \mu \mathrm{g} / \mathrm{ml}$ (dissolved in $10 \%$ DMSO). The mixtures were mixed well and incubated in the dark for $30 \mathrm{~min}$. The reduction of DPPH absorption was measured at $515 \mathrm{~nm}$ using a plate reader. Rutin and quercetin were used as the positive controls. All determinations were performed in triplicate. The DPPH radical scavenging activity was calculated using the following equation:

$$
\begin{aligned}
& \text { Percentage } \text { inhibition }=\left(\text { Absorbance }_{\text {control }}-\text { Absorbance }_{\text {sample }}\right) \\
& / \text { Absorbance }_{\text {control }} \times 100
\end{aligned}
$$

The $\mathrm{IC}_{50}$ value is the concentration of the plant extract required to scavenge $50 \%$ of the total DPPH radicals available.

\section{Cell lines and cell culture}

The human breast adenocarcinoma cell line, MCF-7, and the human mammary epithelial cell line, 184B5, were used in the anti-proliferation study. Assays of antioxidant enzymes and caspase activities, cell cycle analysis, and inhibition of cell migration were performed using MCF-7 cells. Mouse fibroblast cells, 3 T3-L1, were used in the comet assay. All cells were purchased from the American Type Culture Collection (ATCC), USA. MCF-7 cells were routinely cultured in RPMI-1640 (Sigma, UK). 3 T3-L1 cells were grown in Dulbecco's modified Eagle's medium (DMEM) (Lonza, USA). 184B5 cells were cultured in Mammary Epithelial Basal Medium (MEBM) and supplemented with bovine pituitary extract (BPE), hydrocortisone, human epidermal growth factor (hEGF) and insulin using Mammary Epithelial Cell Growth Medium (MEGM) SingleQuots from Lonza, USA. All cells were supplemented with $10 \%(\mathrm{v} / \mathrm{v})$ fetal bovine serum (FBS), $100 \mathrm{IU} /$ $\mathrm{ml}$ penicillin and $100 \mu \mathrm{g} / \mathrm{ml}$ streptomycin. Cells were grown at $37^{\circ} \mathrm{C}$ in a humidified incubator with $5 \% \mathrm{CO}_{2}$.

\section{Anti-proliferative activity}

The inhibition of MCF-7 cell proliferation by $C$. sativum extracts was estimated using the MTT (3-(4,5-dimethylthiazol-2-yl)-2,5-diphenyltetrazolium) bromide assay as described by Mosmann [19]. The ethyl acetate extract of 
C. sativum root showed the best antiproliferative activity on MCF-7 and was assessed for its toxicity on the human mammary cell line, 184B5. Briefly, cells supplemented with $5 \%$ FBS were seeded $\left(5 \times 10^{3}\right.$ cells/well $)$ in 96-well microtiter plates and cultured at $37^{\circ} \mathrm{C}$ in a humidified atmosphere of $5 \% \mathrm{CO}_{2}$. After $24 \mathrm{~h}$ of incubation, the cells were treated with various concentrations of extract $(0-500 \mu \mathrm{g} / \mathrm{ml})$ for another $48 \mathrm{~h}$. Vehiclecontrol wells with cells only and diluent-control wells with similar DMSO concentrations as in treatment were included. At the end of the incubation period, $10 \mu \mathrm{l}$ of $5 \mathrm{mg} / \mathrm{ml}$ MTT bromide in phosphate-buffered saline (PBS) was added to each well. The plates were reincubated for a further $4 \mathrm{~h}$ after which media and MTT were removed by aspiration. DMSO (100 $\mu \mathrm{l})$ was added to each well to dissolve the formazan crystals. Absorbance was read using a microtiter plate reader at $595 \mathrm{~nm}$. All measurements were performed in triplicate. The percentage inhibition of cell proliferation was calculated by the following formula:

$$
\begin{gathered}
\text { Percentage inhibition }=\left(\text { Absorbance }_{\text {control }}-\text { Absorbance }_{\text {treated }}\right) \\
\text { / } \text { Absorbance }_{\text {control }} \times 100
\end{gathered}
$$

\section{Estimation of antioxidant enzymes Preparation of cell lysate}

MCF-7 cells were seeded in a 6-well plate $\left(1.5 \times 10^{6}\right.$ cells/well) in RPMI-1640 supplemented with 5\% FBS. After $24 \mathrm{~h}$, cells were treated with the ethyl acetate extract of C. sativum roots at a final extract concentration of $200 \mu \mathrm{g} / \mathrm{ml}\left(\mathrm{IC}_{50}\right.$ concentration as determined from the MTT assay) in the well. DMSO was used to replace extracts in the untreated control samples. Cells were treated for $0,6,9,15,24$ and 48 h. Following incubation, cells were washed with PBS, harvested using a cell scraper and collected for centrifugation at $1,000 \mathrm{rpm}$ for $5 \mathrm{~min}$ at $4^{\circ} \mathrm{C}$. The supernatant was discarded and the cell pellet resuspended in cold PBS. The number of cells was determined by the trypan blue dye exclusion method. Cells were then lysed while on ice using a sonicator and centrifuged for $10 \mathrm{~min}$ at $6,000 \times g$ at $4^{\circ} \mathrm{C}$. The supernatant was used in antioxidant enzyme assays.

\section{Superoxide dismutase (SOD) assay}

The SOD activity in MCF-7 cells treated with test samples was assayed in triplicate using the superoxide dismutase assay kit by Cayman Chemical (USA). The assay uses a tetrazolium salt for detection of superoxide anion radicals generated by xanthine oxidase. The assay was performed according to the manufacturer's protocol. SOD activity was calculated using the following equation:

$$
\begin{aligned}
S O D(U / m l)= & {[(\text { sampleLR-y intercept }) / \text { slope }] } \\
& \times(0.23 \mathrm{ml} / 0.01 \mathrm{ml})
\end{aligned}
$$

One unit is defined as the amount of enzyme needed to exhibit $50 \%$ dismutation of the superoxide anion radical. SOD activity was expressed in $\mathrm{U} / \mathrm{ml}$ per $10^{6}$ cells.

\section{Glutathione peroxidase (GPx) assay}

The GPx activity in MCF-7 cells treated with test samples was assayed in triplicate using the glutathione peroxidase assay kit by Cayman Chemical (USA). This assay measures GPx activity indirectly by a coupled reaction with glutathione reductase. The assay was performed according to the manufacturer's protocol. GPx activity was calculated using the following equation:

$$
\begin{aligned}
\text { GPx } & \text { activity }(\mathrm{nmol} / \mathrm{min} / \mathrm{ml}) \\
= & \left(\text { change in absorbance per } \min / 0.00373 \mu M^{-1}\right) \\
& \times(0.19 \mathrm{ml} / 0.02 \mathrm{ml})
\end{aligned}
$$

One unit is defined as the amount of enzyme that causes the oxidation of $1 \mathrm{nmol}$ of NADPH to $\mathrm{NADP}^{+}$ per min at $25^{\circ} \mathrm{C}$. GPx activity was expressed in nmol/ $\mathrm{min} / \mathrm{ml}$ per $10^{6}$ cells.

\section{Catalase (CAT) assay}

The CAT activity in cells treated with test samples was assayed in triplicate using the catalase assay kit by Cayman Chemical (USA). The assay is based on the reaction of CAT with methanol in the presence of $\mathrm{H}_{2} \mathrm{O}_{2}$ which produces formaldehyde. Formaldehyde is measured colorimetrically using 4-amino-3-hydrazino-5-mercapto-1,2,4triazole (Purpald) as the chromogen. The assay was performed according to the manufacturer's protocol. CAT activity was calculated using the following equation:

$$
\begin{aligned}
& \text { Catalase activity }(\mathrm{nmol} / \mathrm{min} / \mathrm{ml})= \\
& \text { formaldehyde concentration of sample }(\mu M) / 20 \mathrm{~min}
\end{aligned}
$$

One unit is defined as the amount of enzyme that will cause the formation of $1 \mathrm{nmol}$ of formaldehyde per min at $25^{\circ} \mathrm{C}$. The CAT activity was expressed in $\mathrm{nmol} / \mathrm{min} /$ $\mathrm{ml}$ per $10^{6}$ cells.

\section{Colorimetric assays of caspase- $3,-8$ and -9}

A time- and dose-dependent study of caspase- $3,-8$, and -9 activities in MCF-7 cells was performed in triplicate using Caspase-3/CPP32, FLICE/Caspase-8 and Caspase-9 colorimetric assay kits by BioVision (USA). The test assays for the activities of caspase-3, -8 and -9 that recognise the amino acid sequence, DEVD, IETD, and LEHD, respectively. The assay is based on spectrophotometric detection of the chromophore $p$-nitroanilide ( $p \mathrm{NA}$ ), which is released from labeled substrates after cleavage by caspase. In a 6well plate, MCF-7 cells $\left(1.5 \times 10^{6}\right.$ cells/well $)$ were seeded 
with RPMI-1640 containing 5\% FBS. After $24 \mathrm{~h}$ of incubation, cells were treated with C. sativum (root) ethyl acetate extract at a final concentration of $200 \mu \mathrm{g} / \mathrm{ml}\left(\mathrm{IC}_{50}\right)$ and $276 \mu \mathrm{g} / \mathrm{ml}\left(\mathrm{IC}_{70}\right)$ in the well. DMSO was used in place of the extract for control wells. Colchicine for caspase- 3 and mitomycin $C$ for caspases -8 and -9 at $1 \mu \mathrm{M}$ were used as positive controls. Cells were treated for 6 and $24 \mathrm{~h}$ and then harvested. Caspase activities of cell lysates were assayed according to the manufacturer's protocol. Briefly, in a 96-well plate, $50 \mu \mathrm{g}$ of protein sample was diluted in $50 \mu \mathrm{l}$ of cell lysis buffer and $50 \mu$ l of $2 \times$ reaction buffer (containing $10 \mathrm{mM}$ DTT) was added into each well. For the caspase-3 assay, $5 \mu \mathrm{l}$ of $4 \mathrm{mM}$ DEVD- $p$ NA substrate $(200 \mu \mathrm{M}$ final concentration) was added into wells and the mixture incubated at $37^{\circ} \mathrm{C}$ for $2 \mathrm{~h}$. For analysis of caspase- 8 and caspase-9, the substrates IETD- $p$ NA and LEHD- $p$ NA, respectively, were used. The absorbance of the wells was read at $405 \mathrm{~nm}$. The data was presented as fold change.

\section{Cell cycle analysis}

To determine the distribution of extract-treated MCF-7 cells in different phases of the cell cycle, DNA content in cells was detected by propidium iodide (PI) staining and flow cytometry. MCF-7 cells were cultured in $75 \mathrm{~cm}^{2}$ flasks at a density of $4 \times 10^{6}$ cells in 5\% FBS. After 24 h of incubation, cells were treated with the ethyl acetate extract of the roots, at a final concentration of $276 \mu \mathrm{g} / \mathrm{ml}\left(\mathrm{IC}_{70}\right)$ in the flask for another 24, 48 and $72 \mathrm{~h}$. Untreated control samples were performed using DMSO to replace extracts. The cells were collected, washed and fixed in $70 \%$ ethanol at $-20^{\circ} \mathrm{C}$ overnight. Cells were then washed in PBS, stained in $500 \mu \mathrm{l}$ of $\mathrm{PI} / \mathrm{RNase}$ staining buffer (Becton Dickinson, USA) and incubated in RT for $15 \mathrm{~min}$ in the dark. Cell cycle phase distribution was determined using BD FACSCanto II flow cytometer instrument and BD FACSDiva software (Becton Dickinson, USA). A total of 15,000 events per sample were collected for analysis. The fluorescence intensity of the sub- $G_{1}$ cell fraction represents the apoptotic cell population.

\section{Scratch motility assay}

MCF-7 cells $\left(3.5 \times 10^{5}\right.$ cells/well $)$ were seeded in a 24well plate and grown for $24 \mathrm{~h}$. The confluent cell monolayer was then scratched vertically with a pipette tip, washed twice with PBS and incubated with media containing C. sativum (root) ethyl acetate extract (0, 100, 150, 200, 250 and $300 \mu \mathrm{g} / \mathrm{ml}$ ) with 5\% FBS. $\mathrm{H}_{2} \mathrm{O}_{2}$ was added into each well at a final concentration of $1 \mu \mathrm{M}$ in the cell suspension to stimulate the proliferation and migration of MCF-7 cells. The number of cells in the denuded area were photographed and counted at 0 - and 24-h incubation. The experiment was performed in triplicate. The percent inhibition was calculated as described by Sato \& Rifkin [20]. Percent inhibition $=100-[$ (cell no. in denuded area of sample / cell no. in denuded area of control) $\times 100$ ].

\section{Comet assay}

In a 12-well culture plate, 3 T3-L1 mouse fibroblasts $\left(1 \times 10^{5}\right.$ cells/well) were cultured in DMEM with $10 \%$ FBS for $24 \mathrm{~h}$. The cells were pre-treated with the root ethyl acetate extract at concentrations of $100-400 \mu \mathrm{g} / \mathrm{ml}$ in the well for another $24 \mathrm{~h}$. The control was performed using DMSO to replace extracts. After pre-treatment, cells were exposed to $100 \mu \mathrm{M}$ of $\mathrm{H}_{2} \mathrm{O}_{2}$ (final concentration in the cell suspension) for $60 \mathrm{~min}$ on ice to induce DNA damage. Following $\mathrm{H}_{2} \mathrm{O}_{2}$ exposure, cells were harvested using a cell scraper, centrifuged and resuspended in $1 \mathrm{ml}$ of PBS for use in comet assay [21]. Briefly, $25 \mu \mathrm{l}$ of the cell suspension was mixed with $75 \mu \mathrm{l}$ of $0.6 \%$ low melting agarose. The suspension was spread on a frosted microscopic slide pre-coated with $250 \mu \mathrm{L}$ of $0.8 \%$ normal melting agarose, covered with a cover slip, and then allowed to solidify on ice for $10 \mathrm{~min}$. The cover slips were removed and the slides were immersed in cold lysis solution containing $1 \%$ sodium dodecyl sulfate, $2.5 \mathrm{M}$ $\mathrm{NaCl}, 100 \mathrm{mM} \mathrm{Na}{ }_{2}$ EDTA, 1\% Triton X-100 and 10\% DMSO (with the DMSO added just before use) for one hour at $4{ }^{\circ} \mathrm{C}$ in the dark. Then, slides were arranged in an electrophoresis tank filled with pre-chilled electrophoretic buffer ( $1 \mathrm{mM} \mathrm{Na}{ }_{2}$ EDTA and $300 \mathrm{mM} \mathrm{NaOH}$ ) and incubated for $20 \mathrm{~min}$. Electrophoresis was conducted in the same buffer, in a horizontal chamber, at $25 \mathrm{~V}$ (300 mA) for $20 \mathrm{~min}$ using a power supply (CBS Scientific company, USA). The slides were washed with $0.4 \mathrm{M}$ Tris- $\mathrm{HCl}$ (pH 7.5) and stained with $20 \mu \mathrm{g} / \mathrm{ml}$ ethidium bromide for viewing under a BX50 fluorescence microscope (Olympus, Japan). Electrophoresis of the samples separates intact DNA from damaged fragments. The comet tail length is associated with DNA damage. Greater tail length signifies greater DNA damage [21]. A total of 50 individual cells were screened per slide [22]. The assay was carried out in triplicate. The comet tail length was measured using an ocular micrometer.

Results were expressed in\% DNA protection calculated by the following formula:

$$
\begin{array}{r}
D N A \operatorname{protection}(\%)=\left(\text { tail length }_{\text {control }}-\text { tail length }_{\text {treatment }}\right) \\
/ \text { tail length }_{\text {control }} \times 100
\end{array}
$$

\section{Identification of compounds}

\section{High performance liquid chromatography (HPLC) analysis}

The C. sativum (root) ethyl acetate extract was subjected to acid hydrolysis to release free polyphenols from their glycosides according to the method of Nuutila, Kammiovirta, \& Oksman-Caldentey [23], with slight modifications. Briefly, $20 \mathrm{mg}$ of dried extract in $0.4 \mathrm{ml}$ of $6 \mathrm{~N} \mathrm{HCl}$ and 
$1.6 \mathrm{ml}$ of HPLC grade methanol with $20 \mathrm{mM}$ butylated hydroxytoluene (BHT) as antioxidant was heated at $90^{\circ} \mathrm{C}$ for $2 \mathrm{~h}$. The mixture was centrifuged at 10,000 rpm for $5 \mathrm{~min}$ and the supernatant was filtered through a $0.2 \mu \mathrm{m}$ syringe filter and stored at $4^{\circ} \mathrm{C}$ for HPLC analysis. HPLC analysis was performed using a SPD-20A HPLC system (Shimadzu, Japan). Reverse phase separation was performed at $40^{\circ} \mathrm{C}$ using a Purospher STAR RP-18 endcapped column $(5 \mu \mathrm{m})$ (Merck, Germany). The mobile phase consisted of trifluoroacetic acid in ultrapure water at $\mathrm{pH} 2.6$ (solvent A) and acetonitrile (solvent B). The gradient program consisted of: $0 \%$ to $12.5 \%$ B for $2.5 \mathrm{~min}, 12.5 \%$ to $100 \%$ B for $17.5 \mathrm{~min}$ and $100 \%$ B for $10 \mathrm{~min}$. The flow rate was kept at $1 \mathrm{ml} / \mathrm{min}$ and injection volume was $10 \mu \mathrm{l}$. The chromatogram peaks were detected at $254 \mathrm{~nm}$. Data acquisition and processing was performed using LCsolution software (Shimadzu, Japan). The compounds were identified by comparing the retention times of peaks with standards. The extract was then spiked with the standards to confirm their presence. Unidentified peaks were collected manually and the mobile phase was air dried. The dried fraction (referred to as fraction S1) was stored at $4^{\circ} \mathrm{C}$ for analysis with GC-MS.

\section{Gas chromatography-mass spectrometry (GC-MS) analysis}

Prior to GC-MS analysis, chemical derivatisation was performed to reduce the polarity of functional groups by reconstituting $400 \mu \mathrm{g}$ of the dried fraction S1 (unidentified peaks collected from HPLC) with $500 \mu \mathrm{l}$ of HPLC grade ethyl acetate and $20 \mu \mathrm{l}$ of N,O-bis(trimethylsilyl) trifluoroacetamide (BSTFA), and heated at $70^{\circ} \mathrm{C}$ for $40 \mathrm{~min}$. The GC-MS analyses were carried out in a GCMS-QP2010 system (Shimadzu, Japan) fitted with a ZB-5 (30 $\mathrm{m} \times 0.25 \mathrm{~mm}$ i.d.) capillary column (Phenomenex, USA). The carrier gas was helium with a flow rate of $1.08 \mathrm{ml} / \mathrm{min}$. The column temperature was set at $100^{\circ}$ $\mathrm{C}$ for $5 \mathrm{~min}, 100-275^{\circ} \mathrm{C}$ at $10^{\circ} \mathrm{C} / \mathrm{min}$, and finally held for $20 \mathrm{~min}$ in $275^{\circ} \mathrm{C}$. Sample volume injected was $1 \mu \mathrm{l}$ with a split ratio of $2: 1$. The injector temperature was $250^{\circ} \mathrm{C}$ and the detector temperature was $290^{\circ} \mathrm{C}$. The MS operating parameters were: ionisation potential, $70 \mathrm{eV}$, ion source temperature, $200^{\circ} \mathrm{C}$, solvent delay, $3.0 \mathrm{~min}$, scan speed, $2500 \mathrm{amu} / \mathrm{s}$, scan range, 40-500 amu and detector voltage, $1.5 \mathrm{kV}$. Compound identification was verified based on mass spectral data by computer matching with Wiley 229, NIST 107, NIST 21 and PMW_tox2 libraries.

\section{Statistical analysis}

Data are presented as mean \pm standard deviation (SD). Statistical analyses were performed by one-way analysis of variance (ANOVA) with Tukey's multiple comparisons and the Student's $t$-test. A P-value of $<0.05$ was considered statistically significant. Pearson correlation coefficient was used to assess the correlation between TPC, FRAP and DPPH radical scavenging activity. SPSS, version 18.0 (Chicago, Ill, USA) and Microsoft Excel 2007 (Roselle, Ill, USA) statistical software were used for the statistical and graphical evaluations.

\section{Results}

\section{Total phenolic content}

The amount of total phenolics in extracts of $C$. sativum ranged from $1.73 \pm 0.49$ to $31.38 \pm 2.75 \mathrm{mg}$ GAE/g (Table 1). In both of the plant parts (root and leaves), the ethyl acetate extracts showed the highest TPC values of $31.38 \pm 2.75 \mathrm{mg} \mathrm{GAE} / \mathrm{g}$ (root) and $24.57 \pm 0.70 \mathrm{mg}$ $\mathrm{GAE} / \mathrm{g}$ (leaf and stem).

\section{Ferric reducing antioxidant power}

Among C. sativum root extracts, the ethyl acetate extract had the highest FRAP value of $0.129 \pm 0.007 \mathrm{mmol} / \mathrm{g}$ (Table 1). As for the leaf and stem, highest FRAP value was seen in the dichloromethane extract $(0.136 \pm$ $0.008 \mathrm{mmol} / \mathrm{g})$.

\section{DPPH radical scavenging activity}

The leaf and stem aqueous extract had the lowest $\mathrm{IC}_{50}$ value of $1335.0 \pm 37.7 \mu \mathrm{g} / \mathrm{ml}$ (Table 1). As for the root, the ethyl acetate extract which had highest FRAP value, also displayed highest DPPH radical scavenging activity $\left(\mathrm{IC}_{50}=2348.3 \pm 184.1 \mu \mathrm{g} / \mathrm{ml}\right)$ among root extracts.

\section{Correlation analyses of TPC with FRAP and DPPH radical scavenging activity}

The relationship between phenolic content with FRAP and DPPH scavenging activity of plant extracts were evaluated by Pearson correlation analyses. A strong and statistically significant positive correlation was identified between the phenolic content and FRAP values of the root $(r=0.982, \mathrm{P}<0.01)$ while a weak positive correlation was seen between its TPC and DPPH scavenging activity $(r=0.663, \mathrm{P}<0.01)$ (Table 2$)$. As for the leaf and stem, significant positive correlation was observed between its TPC and DPPH scavenging activity $(r=0.906$, $\mathrm{P}<0.01)$.

\section{Anti-proliferative activity}

The anti-proliferative activity of C. sativum extracts was investigated on the breast adenocarcinoma cell line, MCF7 , using the MTT assay. Results were expressed as $20 \%$ inhibitory concentration $\left(\mathrm{IC}_{20}\right)$ and $50 \%$ inhibitory concentration $\left(\mathrm{IC}_{50}\right)$ (Table 3). Among the five extracts analyzed from $C$. sativum root, the ethyl acetate extract exhibited the best antiproliferative activity with the lowest $\mathrm{IC}_{50}$ value of $200.0 \pm 2.6 \mu \mathrm{g} / \mathrm{ml}$. Among extracts of the leaf and stem, the hexane extract showed the lowest $\mathrm{IC}_{50}$ value $(432.3 \pm$ $41.0 \mu \mathrm{g} / \mathrm{ml})$. As the root ethyl acetate extract displayed the 
Table 1 Phenolic content, ferric reducing antioxidant power and DPPH radical scavenging activity of $C$. sativum extracts

\begin{tabular}{cccc}
\hline Plant extract/positive controls & $\begin{array}{c}\text { Total phenolic content } \\
\text { (mg GAE/g) }\end{array}$ & $\begin{array}{c}\text { FRAP value } \\
\text { ( } \mathbf{m m o l} / \mathbf{g})\end{array}$ & $\begin{array}{c}\text { DPPH radical scavenging activity } \\
(\boldsymbol{\mu g} / \mathbf{m l})\end{array}$ \\
\hline C. sativum (root) Ethyl acetate & $31.38 \pm 2.75$ & $0.129 \pm 0.007$ & $2348.3 \pm 184.1$ \\
C. sativum (leaf and stem) & $24.57 \pm 0.70$ (Ethyl acetate) & $0.136 \pm 0.008$ (Dichloromethane) & $1335.0 \pm 37.7$ (Aqueous) \\
$\quad$ Positive control & & & $42.7 \pm 2.3$ \\
$\quad$ Rutin & $649.93 \pm 13.34$ & $1.789 \pm 0.214$ & $22.2 \pm 0.9$ \\
Quercetin & $1275.62 \pm 56.03$ & $14.444 \pm 0.934$ & \\
\hline
\end{tabular}

Each value is expressed as mean \pm SD $(n=3)$.

$I C_{50}$ values are presented for the DPPH radical scavenging activity.

All values are significantly different at $\mathrm{P}<0.05$ compared to the negative control as tested by the Student's $t$-test.

best anti-proliferative activity, subsequent analyses focused on this extract and its effect on MCF-7 cells. The ethyl acetate extract of the root showed less toxicity on the nonmalignant human breast epithelial cell line, 184B5, with an $\mathrm{IC}_{50}$ value of $317.0 \pm 9.6 \mu \mathrm{g} / \mathrm{ml}$ compared to MCF-7 cells (Table 3 ).

\section{Estimation of antioxidant enzymes}

Antioxidant enzyme activities in root ethyl acetate extract-treated and -untreated MCF-7 cells were estimated. Treated cells showed increasing SOD activity (from 6$48 \mathrm{~h}$ ) compared to the untreated cells (Figure 1A). The GPx activity in treated cells increased from 6-9 h and then decreased from 24-48 h (Figure 1B) while CAT activity increased from $0-9 \mathrm{~h}$ and then decreased until $48 \mathrm{~h}$ (Figure $1 \mathrm{C}$ ).

\section{Activity of caspase- $3,-8$ and -9}

The results indicated that activities of caspases-3, -8 and -9 were significantly enhanced in MCF-7 cells treated with the root extract for $24 \mathrm{~h}$ compared to untreated cells (Table 4). The activities of caspase- $3,-8$, and -9 in cells treated with $200 \mu \mathrm{g} / \mathrm{ml}$ of extract for $24 \mathrm{~h}$ increased by 1.20, 1.16 and 1.12 fold, respectively, compared to untreated cells. At treatment with $276 \mu \mathrm{g} / \mathrm{ml}$ of extract for $24 \mathrm{~h}$, the activities of caspase-3, -8 , and -9 increased by $1.28,1.21$ and 1.30 fold, respectively, compared to untreated cells.

\section{Cell cycle analysis}

Flow cytometric analysis of DNA content and cell cycle distribution was performed to determine the ability of $C$.

Table 2 Correlation analyses of the total phenolic content and antioxidant activities of $C$. sativum extracts

\begin{tabular}{ccc}
\hline Plant & \multicolumn{2}{c}{ Pearson correlation $(\boldsymbol{r})$ value } \\
\cline { 2 - 3 } & TPC/FRAP & TPC/DPPH \\
\hline C. sativum (root) & $0.982^{*}$ & $0.663^{*}$ \\
C. sativum (leaf and stem) & 0.300 & $0.906^{*}$ \\
\hline
\end{tabular}

TPC, total phenolic content; FRAP, ferric reducing antioxidant power; DPPH, 1,1-diphenyl-2-picryl hydrazyl radical scavenging activity.

* Correlation is significant at the 0.01 level. sativum root extract to induce MCF-7 cell cycle arrest and apoptosis. The sub-G1 population of cells (apoptotic population) increased significantly $(\mathrm{P}<0.01)$ in a timedependent manner as compared to the control (Table 5). The decrease in the $S$ phase population was accompanied by significantly increased $G_{2} / M$ phase population $(\mathrm{P}<0.01)$ after 24 and $48 \mathrm{~h}$ treatment compared to the control (Figure 2), indicating cell cycle arrest at the $G_{2}$ / $\mathrm{M}$ phase in treated cells. At $72 \mathrm{~h}$, treated cells had no increment in the $G_{2} / M$ population (Figure 2) but increased in the sub-G1 population compared to the control (Table 5), suggesting that cells were arrested at the $G_{2} / M$ phase followed by significant apoptotic cell death over time.

Inhibition of $\mathrm{H}_{2} \mathrm{O}_{2}$-induced MCF-7 cell migration using the scratch motility assay

The scratch motility assay displayed the ability of the root extract to suppress $\mathrm{H}_{2} \mathrm{O}_{2}$-induced migration of MCF-7 cells in a denuded area. The extract inhibited cell migration induced by $\mathrm{H}_{2} \mathrm{O}_{2}$ following a dose-dependent pattern (Figure 3). At $150 \mu \mathrm{g} / \mathrm{ml}$ of extract, inhibition of MCF-7 migration in the denuded area was $60 \pm 3 \%$. At higher extract concentrations, the percent inhibitions of MCF-7 migration increased up to $91 \pm 0 \%(250 \mu \mathrm{g} / \mathrm{ml})$ and $94 \pm 1 \%(300 \mu \mathrm{g} / \mathrm{ml})$.

\section{DNA protective activity}

The protective effect of the C. sativum root extract on 3 T3-L1 cells from $\mathrm{H}_{2} \mathrm{O}_{2}$-induced DNA damage was investigated using the comet assay. Fibroblasts pre-treated with the extract at $100-400 \mu \mathrm{g} / \mathrm{ml}$ showed a significant dose-dependent increase in DNA protection $(\mathrm{P}<0.05)$ compared to the control (without extract treatment) (Table 6). At $400 \mu \mathrm{g} / \mathrm{ml}$ of extract pretreatment, DNA protection was $21.5 \pm 6.6 \%$.

\section{Identification of compounds in C. sativum root ethyl acetate extract}

The compounds in C. sativum root ethyl acetate extract were identified by HPLC and GC-MS analyses. Figure 4 shows the HPLC chromatogram of C. sativum (root) 
Table 3 Summary of the anti-proliferative activities of C. sativum extracts on MCF-7 and $184 B 5$ cell lines

\begin{tabular}{|c|c|c|c|c|}
\hline \multirow[t]{2}{*}{ Plant extract } & \multicolumn{2}{|c|}{ MCF-7 } & \multicolumn{2}{|c|}{ 184B5 } \\
\hline & $\mathrm{IC} \mathrm{C}_{20}(\mu \mathrm{g} / \mathrm{ml})$ & $\mathrm{IC}_{50}(\mu \mathrm{g} / \mathrm{ml})$ & $\mathrm{IC}_{20}(\mu \mathrm{g} / \mathrm{ml})$ & $\mathrm{IC}_{50}(\mu \mathrm{g} / \mathrm{ml})$ \\
\hline C. sativum (root) Ethyl acetate & $100.0 \pm 1.7$ & $200.0 \pm 2.6$ & $174.3 \pm 26.0$ & $317.0 \pm 9.6$ \\
\hline C. sativum (leaf and stem) Hexane & $138.0 \pm 8.7$ & $432.3 \pm 41.0$ & ND & ND \\
\hline
\end{tabular}

Each value is expressed as mean \pm SD $(n=3)$.

$\mathrm{ND}=$ Not Detected.

ethyl acetate extract. Ascorbic acid and $p$-coumaric acid were detected in the extract. Peak 3 is butylated hydroxytoluene, an antioxidant added to C. sativum (root) ethyl acetate sample during extract preparation for HPLC analysis. Several peaks that did not correspond to the standards used in the HPLC analysis were observed in the chromatogram between retention times 15-20 $\mathrm{min}$. The unidentified peaks marked as fraction S1 (Figure 4) were collected and analysed by GC-MS. Cinnamic acid, 4,4,5,7,8-pentamethyl-3,4-

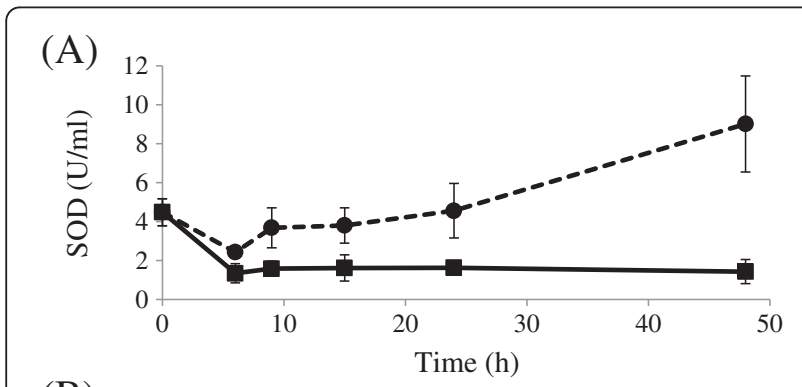

(B)

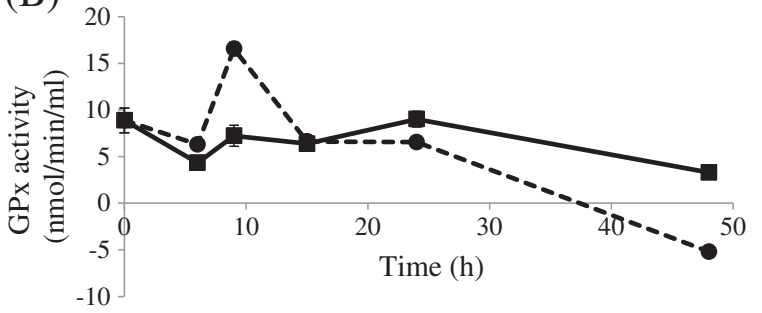

(C) 60

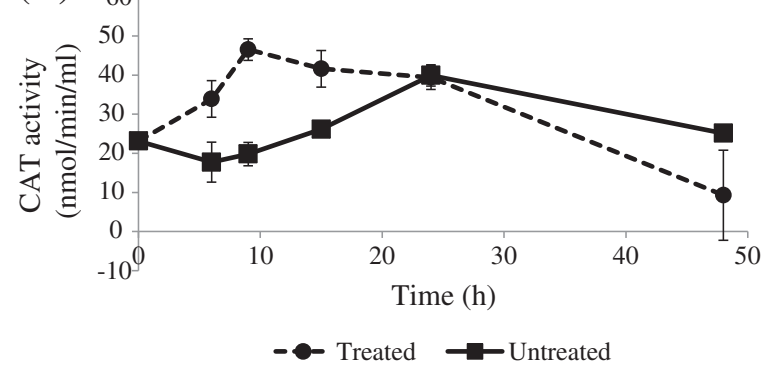

Figure 1 Antioxidant enzyme activities in untreated and treated MCF-7 cells with C. sativum root extract. MCF-7 cells $\left(1.5 \times 10^{6}\right)$ were treated with $C$. sativum root ethyl acetate extract at $200 \mathrm{\mu g} / \mathrm{ml}$ (IC $C_{50}$ concentration) for 0, 6, 9, 15, 24 and $48 \mathrm{~h}$. DMSO was used to replace the extract in untreated cells. (A) Superoxide dismutase (SOD) activity is expressed in $\mathrm{U} / \mathrm{ml}$ per $10^{6}$ cells, while (B) glutathione peroxidase (GPX) and (C) catalase (CAT) activities are expressed in $\mathrm{nmol} / \mathrm{min} / \mathrm{ml}$ per $10^{6}$ cells. Results are expressed as mean $\pm S D(n=3)$.
2H-isocoumarin-3-one, 1,3,4 tris(trimethylsilyloxy)octadecan-2-amine and L-valine were identified from GC-MS analyses. These four compounds most possibly represent the four unidentified peaks of fraction S1 (Figure 4).

\section{Discussion}

C. sativum has been popularly used as a dietary herb to flavor food and also treat ailments and to promote health and well-being. In this study, the antioxidant, anticancer and MCF-7 cell migration inhibitory activities of C. sativum were investigated. The DNA protective ability in normal cells was also investigated.

Antioxidant activities of C. sativum reported in literature mostly focused on the aerial parts of the herb. In this study, we showed the antioxidant activities of $C$. sativum root, and the leaf and stem. As antioxidant activities can be affected by location and growth conditions of the plant, antioxidant data on the leaf and stem is appropriate. The nature of the extracting solvent is one of the most important factors in the extraction of antioxidants and bioactive compounds. Hence, we used a range of non-polar to polar solvents to sequentially extract compounds from C. sativum and the extracts were tested for antioxidant potential and inhibitory activities on cancer cells. Plant antioxidant studies reported that ethyl acetate allowed for the selective removal of nonphenolic compounds and achieved the highest phenolic

Table 4 Activities of caspase-3, -8 and -9 in MCF-7 cells treated with $C$. sativum root extract

\begin{tabular}{cccc}
\hline Treatment & \multicolumn{3}{c}{ Fold change compared to control } \\
\cline { 2 - 4 } & Caspase-3 & Caspase-8 & Caspase-9 \\
\hline Control & $1.00 \pm 0.00$ & $1.00 \pm 0.00$ & $1.00 \pm 0.00$ \\
\hline $\boldsymbol{6} \boldsymbol{h}$ & & & \\
$200 \mu \mathrm{g} / \mathrm{ml}$ & $0.87 \pm 0.02$ & $0.83 \pm 0.00$ & $0.84 \pm 0.03$ \\
$276 \mu \mathrm{g} / \mathrm{ml}$ & $0.86 \pm 0.03$ & $0.87 \pm 0.03$ & $0.88 \pm 0.04$ \\
Positive control & $0.91 \pm 0.01$ & $0.87 \pm 0.01$ & $0.87 \pm 0.02$ \\
\hline $\mathbf{2 4} \boldsymbol{h}$ & & & \\
$200 \mu \mathrm{g} / \mathrm{ml}$ & $1.20 \pm 0.02^{*}$ & $1.16 \pm 0.02^{*}$ & $1.12 \pm 0.03^{*}$ \\
$276 \mu \mathrm{g} / \mathrm{ml}$ & $1.28 \pm 0.02^{*}$ & $1.21 \pm 0.03^{*}$ & $1.30 \pm 0.01^{*}$ \\
Positive control & $1.06 \pm 0.01^{*}$ & $1.06 \pm 0.02^{*}$ & $1.07 \pm 0.02^{*}$ \\
\hline
\end{tabular}

The positive controls used were colchicine (caspase-3) and mitomycin C (caspase-8 and -9) at $1 \mu \mathrm{M}$.

Values are expressed as fold change compared to control, mean $\pm S D(n=3)$. *Values are significantly different at $\mathrm{P}<0.05$ compared to control as tested by the Student's $t$-test. 
Table 5 Sub-G 1 populations in untreated (control) and treated MCF-7 cells with $C$. sativum root extract

\begin{tabular}{ccc}
\hline Time (h) & \multicolumn{2}{c}{ Sub-G $\mathbf{1}$ (\%) } \\
\cline { 2 - 3 } & Control & Treated \\
\hline 24 & $0.73 \pm 0.60$ & $18.53 \pm 1.25^{*}$ \\
48 & $2.59 \pm 2.16$ & $35.67 \pm 2.61{ }^{*}$ \\
72 & $0.78 \pm 1.34$ & $42.46 \pm 2.066^{*}$ \\
\hline
\end{tabular}

Each value is expressed as mean \pm SD $(n=3)$.

${ }^{*} \mathrm{P}<0.01$ compared to the control as tested by the Student's $t$-test. content [24]. The ethyl acetate extracts of C. sativum leaf and seed have been reported with highest phenolic content [14,15]. Likewise, our study showed highest phenolic content in ethyl acetate extracts of $C$. sativum parts, with the highest TPC in the root. The root ethyl acetate extract also had highest FRAP and DPPH scavenging activities among extracts of the root. Antioxidant activities of medicinal plants have been attributed to their phenolic content [25]. Our correlation analyses showed positive correlation between the phenolic content of $C$. sativum (root) with FRAP and DPPH scavenging activities.

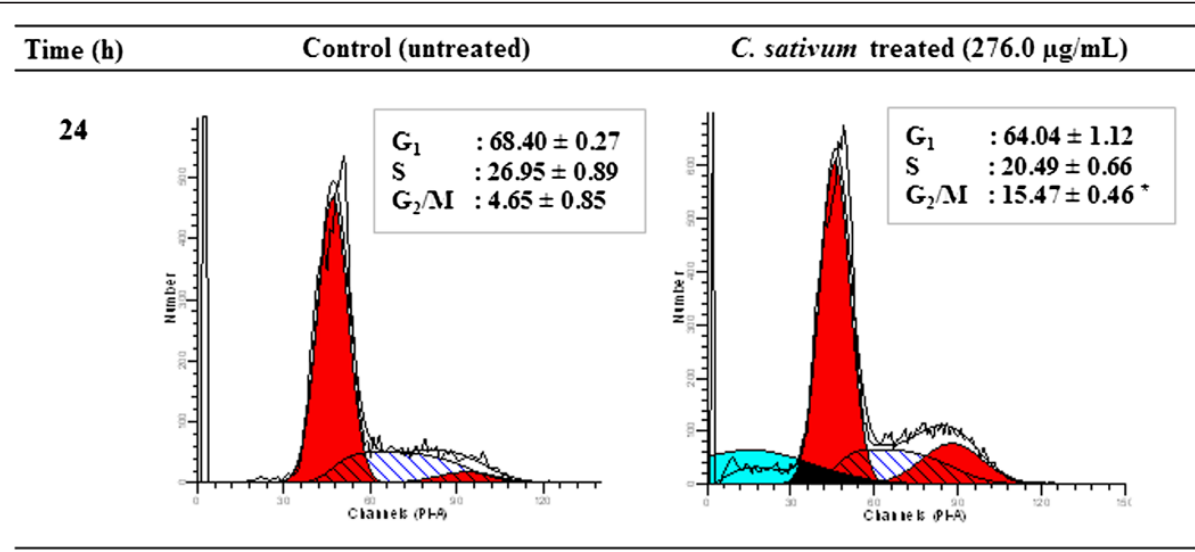

48
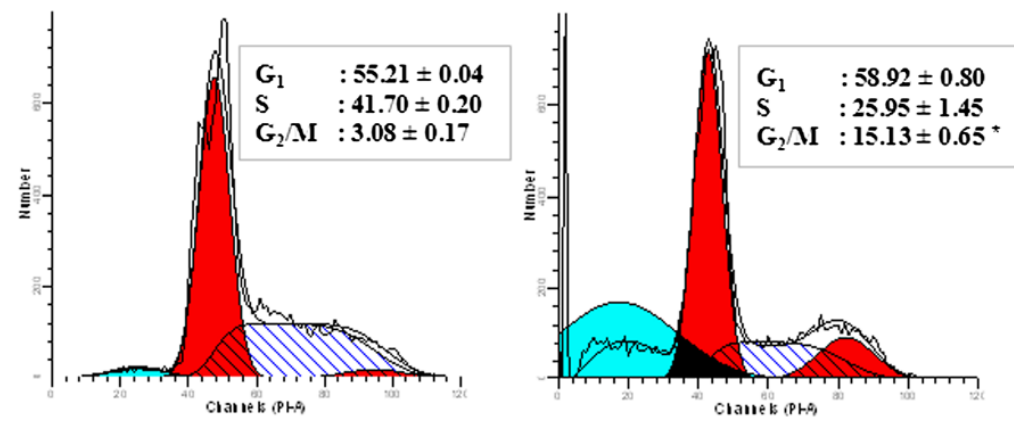

72
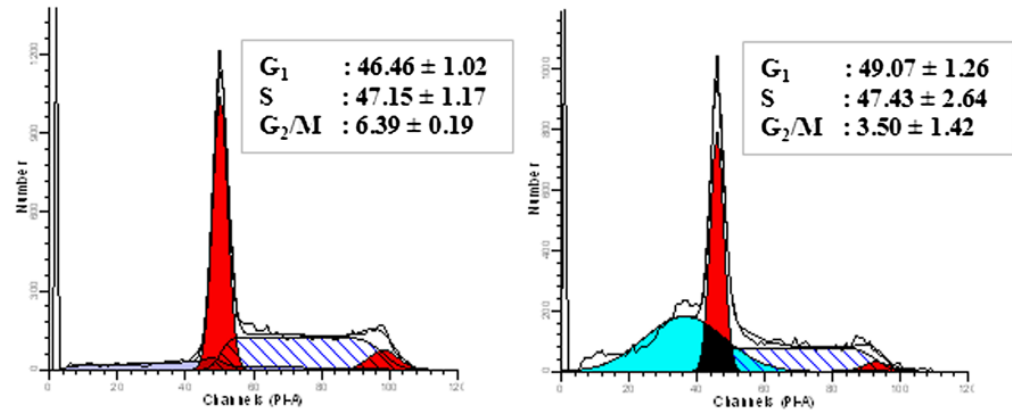

Figure 2 C. Sativum root extract induces cell cycle arrest at $G_{2} / M$ phase in MCF-7 cells. The cell cycle distribution was determined by propidium iodide staining and flow cytometry. MCF-7 cells were treated with the root ethyl acetate extract $(276.0 \mu \mathrm{g} / \mathrm{ml})$ for $24,48 \mathrm{and} 72 \mathrm{~h}$. Untreated cells at each time point were included as controls. The DNA histogram shows the distribution and the percentage of cells in phases of the cell cycle. Results are the mean \pm SD of 3 independent experiments. ${ }^{*} P<0.01$ compared to the control as tested by the Student's $t$-test. Each DNA histogram represents one of the three independent experiments. 


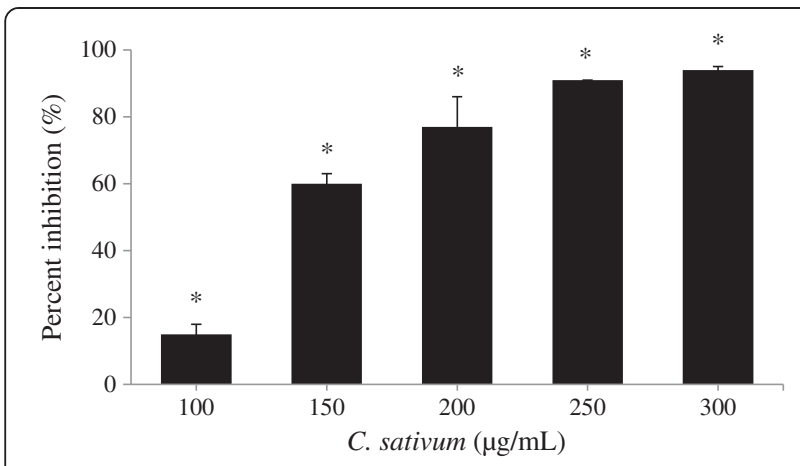

Figure 3 Inhibition of $\mathrm{H}_{2} \mathrm{O}_{2}$-induced MCF-7 cell migration by $\mathrm{C}$. sativum root ethyl acetate extract. Results are presented as mean $\pm S D(n=3) .{ }^{*} P<0.05$ compared to the control (without extract) as tested by the Student's $t$-test.

This implies that phenolic compounds in C. sativum root extracts have reductive abilities and may provide antioxidative protection in actual biological systems by donating electrons to radicals. This study also showed that the leaf and stem dichloromethane and aqueous extract had highest FRAP and DPPH scavenging activity, respectively. In a different study, the aqueous extract of $C$. sativum leaf and shoots exhibited antioxidant activity in a $\beta$-carotene/ linoleic acid model [26]. Our study together with those reported in literature show that the various parts of $C$. sativum have antioxidant properties that protect cells from the adverse effects of oxidative stress caused by ROS.

Each extract of C. sativum showed different antiproliferative effects on the MCF-7 cell line, which may be due to extract phytodiversity, different mechanisms of action by compounds in extracts, and the various susceptibility levels of cell lines to extracts [27]. In this study, the root ethyl acetate extract which displayed the highest phenolic content, also showed the best anti-proliferative activitiy in MCF-7 cells. Hence, we selected the root ethyl acetate extract to further analyze its anticancer effects on antioxidant enzymes, caspase activity, cell cycle arrest, and inhibition of cell migration in MCF-7 cells. The protective effect of the extract on $\mathrm{H}_{2} \mathrm{O}_{2}$-induced DNA damage was determined using non-cancerous 3 T3-L1 fibroblasts. Although C. sativum (leaf and stem) dichloromethane and

Table 6 Protection from $\mathrm{H}_{2} \mathrm{O}_{2}$-induced DNA damage in 3 T3-L1 fibroblasts pre-treated with $C$. sativum root extract

\begin{tabular}{cc}
\hline C. sativum $(\boldsymbol{\mu g} / \mathrm{mL})$ & DNA protection $(\%)$ \\
\hline 100 & $3.4 \pm 4.7^{*}$ \\
200 & $6.5 \pm 5.5^{*}$ \\
300 & $13.4 \pm 6.1^{*}$ \\
400 & $21.5 \pm 6.6^{*}$ \\
\hline
\end{tabular}

Means \pm SD are presented $(n=3)$.

* $\mathrm{P}<0.05$ compared to control (without extract treatment), as tested by the Student's $t$-test. aqueous extracts had higher FRAP and DPPH scavenging activity, respectively, compared to the root extract, these extracts exhibited weak antiproliferative activity and were thus not selected for subsequent assays.

High levels of $\mathrm{H}_{2} \mathrm{O}_{2}$ can produce cancer cell death [6]. We showed that MCF-7 cells treated with C. sativum root ethyl acetate extract displayed increasing SOD activity over $48 \mathrm{~h}$ of treatment while GPx and CAT activities decreased from 24-48 h. Antioxidant enzymes are involved in the direct elimination of ROS in cells. SOD converts superoxide anion to $\mathrm{H}_{2} \mathrm{O}_{2}$, while GPx and CAT convert $\mathrm{H}_{2} \mathrm{O}_{2}$ to water and oxygen. As the $\mathrm{H}_{2} \mathrm{O}_{2}$-detoxifying enzymes, GPx and CAT activities decreased with extract treatment, high levels of $\mathrm{H}_{2} \mathrm{O}_{2}$ produced by the increasing SOD activity possibly led to $\mathrm{H}_{2} \mathrm{O}_{2}$ accumulation, leading to MCF-7 cancer cell death [6]. A possible explanation for the decrease in GPx and CAT activity in treated cells from $24-48 \mathrm{~h}$ is due to increasing ROS. CAT can be downregulated by ROS [28] while GPx can be inactivated by peroxides and hydroxyl radicals [29]. Rashad, El-Sayed, Mohamed, \& Ali [30] reported that quinoline derivatives inhibited the growth of MCF-7 cells by similarly increasing the activity of SOD and decreasing CAT and GPx activities, accompanied by a high production of $\mathrm{H}_{2} \mathrm{O}_{2}$ and other free radicals which caused cancer cell death.

There is an added feature in the root extract causing MCF-7 cell death by $\mathrm{H}_{2} \mathrm{O}_{2}$ accumulation. Experimental evidence has shown that cancer cells are more susceptible to $\mathrm{H}_{2} \mathrm{O}_{2}$-induced cell death compared to normal cells [31]. There is a threshold of $\mathrm{H}_{2} \mathrm{O}_{2}$ above which cells cannot survive. Cancer cells have higher levels of $\mathrm{H}_{2} \mathrm{O}_{2}$ than normal cells. A slight elevation of $\mathrm{H}_{2} \mathrm{O}_{2}$ in cancer cells causes their $\mathrm{H}_{2} \mathrm{O}_{2}$ levels to increase above the toxic threshold, making these cells more susceptible to $\mathrm{H}_{2} \mathrm{O}_{2}$-induced cell death [6]. This is shown in our study where the root extract had lower toxicity on the nonmalignant human breast epithelial cell line, 184B5 compared to MCF-7 breast cancer cells. A successful anticancer agent causes cancer cell death without damaging normal cells excessively. A review by Burdock \& Carabin [32] reported on the safety of coriander seed essential oil as an added food ingredient.

The caspase cascade signaling system is an important component in the process of apoptosis. The activation of the downstream pathways of caspase- 8 varies with different cell types. In Type I cells (cells of some lymphoid cell lines), the activation of caspase- 8 directly activates procaspase-3. In Type II cells (cells other than Type I cells), the activation of caspase- 8 causes caspase- 9 activation, which then induces cleavage of procaspase- 3 [33]. As caspase-9 (mitochondrial pathway) is known to be activated following caspase-8 (death receptor pathway) activation in MCF-7 cells (Type II cells) [34], it is 


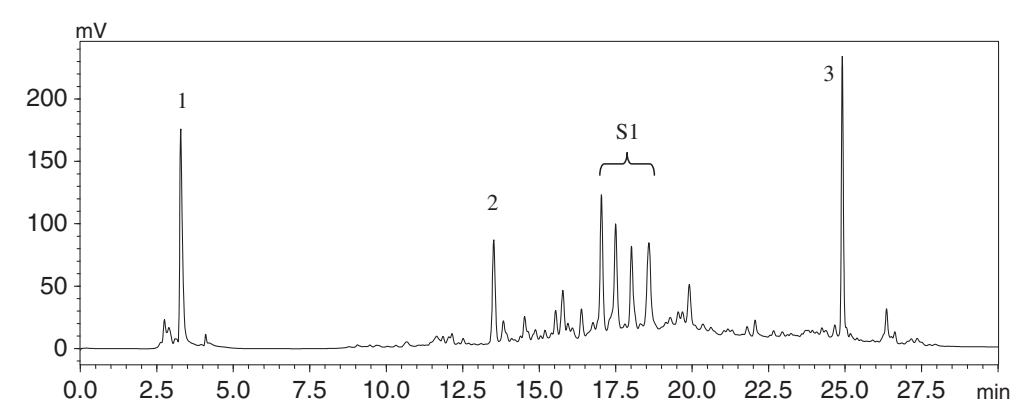

Figure 4 HPLC chromatogram of $C$. sativum root extract. Reverse phase separation was performed at $40^{\circ} \mathrm{C}$ using a Merck Purospher STAR RP-18 endcapped column $(5 \mu \mathrm{m})$. The mobile phase consisted of trifluoroacetic acid in water at pH 2.6 (solvent A) and acetonitrile (solvent B). The gradient program consisted of: $0 \%$ to $12.5 \%$ B for $2.5 \mathrm{~min}, 12.5 \%$ to $100 \%$ B for 17.5 min and 100\% B for 10 min. The flow rate was kept at $1 \mathrm{ml} / \mathrm{min}$ and injection volume was $10 \mu \mathrm{l}$. The eluted peaks were monitored at $254 \mathrm{~nm}$. 1: ascorbic acid; 2: p-coumaric acid; 3: butylated hydroxytoluene; S1: unidentified peaks collected for GC-MS analysis. (BSTFA = N,O-bis(trimethylsilyl)trifluoroacetamide).

postulated that caspase- 8 activation is an initiating event in the apoptotic cell death induced by the root extract which led to the higher activities of caspase- 9 and -3 . The activation of caspase- 3 is an important downstream step in the apoptotic pathway. Caspases-3, -8 and -9 are the main executors of apoptosis [35]. Our study suggest that C. sativum root extract inhibited MCF-7 breast cancer cells by the death receptor and mitochondrial apoptotic pathways as demonstrated by significantly increased caspases-3, -8 and -9 activities compared to the control. Jänicke [36] reported that the MCF-7 cell line from ATCC lacks functional caspase-3. However, there are studies that reported the presence of caspase-3 in MCF-7 [37,38]. In our study, activation of caspase- 3 was observed. The different reports on the presence of caspase- 3 in MCF- 7 could be due to the different variants of MCF-7 cells used [39].

From the flow cytometric analysis, we further confirm that $C$. sativum root extract induced apoptotic cell death in MCF-7 cells, characterized by an increase in sub- $G_{1}$ cells [40]. The extract also caused cell cycle arrest at the $G_{2} / M$ phase. As avoidance of cell cycle arrest is a common alteration in cancer, agents that are able to induce cell cycle arrest can act as a barrier to cancer and are increasingly used in combination with conventional cytotoxic drugs to improve anticancer efficacy and overcome drug resistance [41], thus displaying the potential use of C. sativum root to enhance conventional chemotherapy.

From the scratch motility assay, we showed that $C$. sativum root extract is able to inhibit $\mathrm{H}_{2} \mathrm{O}_{2}$-induced MCF7 cancer cell migration, indicating its potential in preventing metastasis. $\mathrm{H}_{2} \mathrm{O}_{2}$ was used in this experiment to induce migration of MCF-7 cells in the denuded area. The concentration of $\mathrm{H}_{2} \mathrm{O}_{2}(1 \mu \mathrm{M})$ used in this assay has been previously tested in our laboratory and showed increased cell migration and proliferation [22]. Antioxidants in the root extract can decrease $\mathrm{H}_{2} \mathrm{O}_{2}$ levels and may be associated with the prevention of cancer cell proliferation and migration [6].
The comet assay is a quick, simple and sensitive method for the evaluation of DNA damage, mainly single-strand and double-strand breaks in individual cells. $\mathrm{H}_{2} \mathrm{O}_{2}$ produces reactive hydroxyl radicals which can induce strand breaks associated with DNA damage. We showed that $C$. sativum root extract protected $3 \mathrm{~T} 3-\mathrm{L} 1$ cells against $\mathrm{H}_{2} \mathrm{O}_{2}-$ induced DNA damage, suggesting protection from free radical induced carcinogenesis, i.e., chemoprotective activity. A study on spices (ginger, caraway, cumin, cardamom, star anise and fennel) showed a strong positive correlation between DNA protection and phenols [22]. This implies that phenolics from the root extract may have contributed to the observed DNA protective activity. Phenolics might lower $\mathrm{H}_{2} \mathrm{O}_{2}$ levels or hydroxyl radicals by increasing the levels of $\mathrm{H}_{2} \mathrm{O}_{2}$-detoxifying enzymes in cells [15]. From other reports, C. sativum had marked anti-genotoxic and anti-carcinogenic activities against several genotoxicants, like 4-nitro- $o$-phenylenediamine, $m$-phenylenediamine and 2-aminofluorene [42], and protected against carbon tetrachloride-induced hepatotoxicity in rats [8].

We identified ascorbic acid, the phenolics $p$-coumaric acid and cinnamic acid, 4,4,5,7,8-pentamethyl-3,4-2Hisocoumarin-3-one, 1,3,4-tris(trimethylsilyloxy)octadecan-2-amine and the amino acid L-valine in the C. sativum root ethyl acetate extract. Acid hydrolysis was performed on the extract before HPLC analysis. Although hydrolysis may raise questions with respect to sample preparation, analyte stability and recoverability, this step cleaves ester bonds and simplifies the analysis by reducing the number of derivatives [43]. Fraction S1 was derivatized with BSTFA to increase its volatility for GC-MS analysis. Silylation has become the major derivatization technique as the reaction is simple and the byproducts of these reactions are extremely volatile, elute very early, and do not interfere with the analysis [44].

Previous studies reported the presence of ascorbic acid [45], p-coumaric acid [46], cinnamic acid [47] and valine [11] in C. sativum. Isocoumarins such as coriandrones A - 
E, coriandrin and dihydrocoriandrin have been reported in C. sativum [46]. In this study, we identified 4,4,5,7,8pentamethyl-3,4-2H-isocoumarin-3-one in C. sativum root, which was also reported in the essential oil of Dictamnus dasycarpus root bark [48]. HPLC fingerprinting of ethanolic extract of $C$. sativum leaves showed the presence of iso-quercetin and quercetin [49]. In a recent study, the essential oil of C. sativum analyzed by GCMS revealed 39 and 38 components identified from the leaves and stems, respectively. Among the major components reported in the leaves were cyclododecanol (23.11\%), tetradecanal (17.86\%), 2-dodecenal (9.93\%) and 1-decanol (7.24\%). The major components in the stems were phytol (61.86\%), 15-methyltricyclo[6.5.2 $(13,14), 0(7,15)]$-pentadeca-1,3,5,7,9,11,13-heptene (7.01\%), dodecanal (3.18\%), and 1-dodecanol (2.47\%) [50].

Extensive study has been done on ascorbic acid as an antioxidant and pro-oxidant with anticarcinogenic and anticancer properties [51]. Ascorbic acid has been shown to be cytotoxic to MCF-7 and HT-29 cells [52,53] and to induce cell death through the generation of $\mathrm{H}_{2} \mathrm{O}_{2}$ [54]. Generation of oxidative stress due to $\mathrm{H}_{2} \mathrm{O}_{2}$ is associated with the arrest of cancer cell proliferation and triggering of apoptosis [55]. Ascorbic acid has been reported to induce cell cycle arrest at the $\mathrm{G}_{2} / \mathrm{M}$ phase [56] and mitigate tumor metastasis [57]. We observed similarities in the anticancer effects of ascorbic acid reported in literature with those exhibited by the ethyl acetate extract of C. sativum root in this study. Supported by literature and from the results of our study, we postulate that ascorbic acid contributed to the anticancer and antioxidant activities of C. sativum root observed in this study. However, the role of the other compounds reported in the root should not be disregarded as the mixture of compounds in an extract and their possible additive or synergistic action could be responsible for the bioactivities produced by an extract.

Though the anti-proliferative effect of the root extract was not very high, regular addition of $C$. sativum in the diet could contribute to overall health and wellness and protect against diseases like cancer.

\section{Conclusion}

The ethyl acetate extract of C. sativum root has antioxidant and anticancer properties. C. sativum root inhibited DNA damage in fibroblasts and prevented MCF-7 breast cancer cell migration induced by $\mathrm{H}_{2} \mathrm{O}_{2}$, suggesting its potential in cancer prevention and inhibition of metastasis. The herb exhibited anticancer activity in MCF-7 breast cancer cells by affecting antioxidant enzymes leading to $\mathrm{H}_{2} \mathrm{O}_{2}$ accumulation, cell cycle arrest at the $\mathrm{G}_{2} / \mathrm{M}$ phase and apoptotic cell death by the death receptor and mitochondrial apoptotic pathways. We report the presence of ascorbic acid in C. sativum root, a compound well-known for its antioxidant and anticancer properties. Taken together, we showed that $C$. sativum root has medicinal value with regard to its antioxidant and anticancer properties in preventing oxidative stress-related diseases and may be useful as food or supplements used in combination with conventional drugs to enhance the treatment of diseases such as cancer. The scientific study corroborates the use of this herb in traditional medicine.

\section{Competing interest}

The authors declare that they have no competing interests, financially or otherwise.

\section{Authors' contributions}

ELHT performed almost all of the experiments and analyzed the data. JR designed the DNA damage study. SYF supervised part of the study and reviewed the manuscript. MSK conceived, designed, analyzed, supervised the study and rewrote the final manuscript. All authors read and approved the final manuscript.

\section{Acknowledgments}

The authors thank the University of Malaya for supporting this research through the University of Malaya Research Grants: RG004/09AFR, PS250/ 2010B and RG341/11HTM.

Received: 2 July 2013 Accepted: 5 December 2013

Published: 9 December 2013

\section{References}

1. DeSylvia D, Stuber M, Fung CC, Bazargan-Hejazi S, Cooper E: The knowledge, attitudes and usage of complementary and alternative medicine of medical students. Evid-Based Compl Alt 2011. 10.1093/ecam/nen075.

2. Benz CC, Yau C: Ageing, oxidative stress and cancer: paradigms in parallax. Nat Rev Cancer 2008, 8:875-879.

3. Jiménez-Estrada M, Velázquez-Contreras C, Garibay-Escobar A, Sierras-Canchola D, Lapizco-Vázquez R, Ortiz-Sandoval C, Burgos-Hernández A, Robles-Zepeda RE: In vitro antioxidant and antiproliferative activities of plants of the ethnopharmacopeia from northwest of Mexico. BMC Complem Altern M 2013, 13:12.

4. Imlay JA, Linn S: DNA damage and oxygen radical toxicity. Science 1988, 240:1302.

5. Nelson KK, Ranganathan AC, Mansouri J, Rodriguez AM, Providence KM, Rutter JL, Pumiglia K, Bennett JA, Melendez JA: Elevated sod2 activity augments matrix metalloproteinase expression evidence for the involvement of endogenous hydrogen peroxide in regulating metastasis. Clin Cancer Res 2003, 9:424-432.

6. López-Lázaro M: Dual role of hydrogen peroxide in cancer: possible relevance to cancer chemoprevention and therapy. Cancer Lett 2007, 252:1-8.

7. Taraphdar AK, Roy M, Bhattacharya R: Natural products as inducers of apoptosis: implication for cancer therapy and prevention. Curr Sci India 2001, 80:1387-1396

8. Sreelatha S, Padma P, Umadevi M: Protective effects of Coriandrum sativum extracts on carbon tetrachloride-induced hepatotoxicity in rats. Food Chem Toxicol 2009, 47:702-708.

9. Padmaa M: Coriandrum sativum linn: a review. Pharmacol online Newsl 2009, 3:561-573.

10. Asgarpanah J, Kazemivash N: Phytochemistry, pharmacology and medicinal properties of Coriandrum sativum L. Afr J Pharm Pharmaco 2012, 6:2340-2345

11. Oganesyan E, Nersesyan Z, Parkhomenko AY: Chemical composition of the above-ground part of Coriandrum sativum. Pharm Chem J-Ussr 2007, 41:149-153.

12. Kubo I, Fujita K-i, Kubo A, Nihei K-i, Ogura T: Antibacterial activity of coriander volatile compounds against Salmonella choleraesuis. J Agr Food Chem 2004, 52:3329-3332.

13. Momin AH, Acharya SS, Gajjar AV: Coriandrum sativum-review of advances in phytopharmacology. Int J Pharm Sci Res 2012, 3:1233-1239. 
14. Wangensteen $H$, Samuelsen $A B$, Malterud KE: Antioxidant activity in extracts from coriander. Food Chem 2004, 88:293-297.

15. Hashim M, Lincy S, Remya $V$, Teena M, Anila L: Effect of polyphenolic compounds from Coriandrum sativum on $\mathrm{H}_{2} \mathrm{O}_{2}$-induced oxidative stress in human lymphocytes. Food Chem 2005, 92:653-660.

16. Singleton $\mathrm{V}$, Rossi JA: Colorimetry of total phenolics with phosphomolybdic-phosphotungstic acid reagents. Am J Enol Viticult 1965, 16:144-158.

17. Benzie IFF, Strain J: The ferric reducing ability of plasma (FRAP) as a measure of "antioxidant power": the FRAP assay. Anal Biochem 1996, 239:70-76.

18. Cos P, Rajan P, Vedernikova I, Calomme M, Pieters L, Vlietinck AJ, Augustyns K, Haemers A, Berghe DV: In vitro antioxidant profile of phenolic acid derivatives. Free Radical Res 2002, 36:711-716.

19. Mosmann T: Rapid colorimetric assay for cellular growth and survival: application to proliferation and cytotoxicity assays. $J$ Immunol Methods 1983, 65:55-63.

20. Sato $Y$, Rifkin DB: Autocrine activities of basic fibroblast growth factor: regulation of endothelial cell movement, plasminogen activator synthesis, and DNA synthesis. J Cell Biol 1988, 107:1199-1205.

21. Singh NP, McCoy MT, Tice RR, Schneider EL: A simple technique for quantitation of low levels of DNA damage in individual cells. Exp Cell Res 1988, 175:184-191.

22. Jayakumar R, Kanthimathi MS: Dietary spices protect against hydrogen peroxide-induced DNA damage and inhibit nicotine-induced cancer cel migration. Food Chem 2012, 134:1580-1584.

23. Nuutila A, Kammiovirta K, Oksman-Caldentey K-M: Comparison of methods for the hydrolysis of flavonoids and phenolic acids from onion and spinach for HPLC analysis. Food Chem 2002, 76:519-525

24. Conde $E_{1}$ Moure A, Domínguez H, Parajó JC: Fractionation of antioxidants from autohydrolysis of barley husks. J Agr Food Chem 2008, 56:10651-10659.

25. Moirangthem DS, Talukdar NC, Kasoju N, Bora U: Antioxidant, antibacterial, cytotoxic, and apoptotic activity of stem bark extracts of Cephalotaxus griffithii Hook. f. BMC Complem Altern M 2012, 12:30

26. de Almeida ME, Mancini Filho J, Barbosa Guerra N: Characterization of antioxidant compounds in aqueous coriander extract (Coriandrum sativum L.). LWT-Food Sci Technol 2005, 38:15-19.

27. Ford J, Jiang M, Milner J: Cancer-specific functions of SIRT1 enable human epithelial cancer cell growth and survival. Cancer Res 2005, 65:10457-10463.

28. Min JY, Lim SO, Jung G: Downregulation of catalase by reactive oxygen species via hypermethylation of CpG island II on the catalase promoter. FEBS Lett 2010, 584:2427-2432.

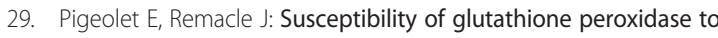
proteolysis after oxidative alteration by peroxides and hydroxyl radicals. Free Radical Bio Med 1991, 11:191-195.

30. Rashad AE, El-Sayed WA, Mohamed AM, Ali MM: Synthesis of new quinoline derivatives as inhibitors of human tumor cells growth. Arch Pharm 2010, 343:440-448

31. Evens AM, Lecane P, Magda D, Prachand S, Singhal S, Nelson J, Miller RA, Gartenhaus RB, Gordon LI: Motexafin gadolinium generates reactive oxygen species and induces apoptosis in sensitive and highly resistant multiple myeloma cells. Blood 2005, 105:1265-1273.

32. Burdock GA, Carabin IG: Safety assessment of coriander (Coriandrum sativum L.) essential oil as a food ingredient. Food Chem Toxicol 2009, 47:22-34.

33. Fan TJ, Han LH, Cong RS, Liang J: Caspase family proteases and apoptosis. Acta Bioch Bioph Sin 2005, 37:719-727.

34. Day TW, Huang S, Safa AR: c-FLIP knockdown induces ligand-independent DR5-, FADD-, caspase-8-, and caspase-9-dependent apoptosis in breast cancer cells. Biochem Pharmacol 2008, 76:1694-1704.

35. Riedl SJ, Shi Y: Molecular mechanisms of caspase regulation during apoptosis. Nat Rev Mol Cell Bio 2004, 5:897-907.

36. Jänicke RU: MCF-7 breast carcinoma cells do not express caspase-3. Breast Cancer Res Tr 2009, 117:219-221.

37. Zhang GP, Lu YY, LV JC, Ou HJ: Effect of ursolic acid on caspase-3 and PARP expression of human MCF-7 cells. Zhongguo Zhong Yao Za Zhi 2006, 31:141-144.

38. Yang HL, Chen CS, Chang WH, Lu FJ, Lai YC, Chen CC, Hseu TH, Kuo CT, Hseu YC: Growth inhibition and induction of apoptosis in MCF-7 breast cancer cells by Antrodia camphorata. Cancer Lett 2006, 231:215-227.

39. Gooch JL, Yee D: Strain-specific differences in formation of apoptotic DNA ladders in MCF-7 breast cancer cells. Cancer Lett 1999, 144:31-37.
40. Shim HY, Park JH, Paik HD, Nah SY, Kim DS, Han YS: Acacetin-induced apoptosis of human breast cancer MCF-7 cells involves caspase cascade, mitochondria-mediated death signaling and SAPK/JNK1/2-c-Jun activation. Mol Cells 2007, 24:95-104.

41. Schwartz GK, Shah MA: Targeting the cell cycle: a new approach to cancer therapy. J Clin Oncol 2005, 23:9408-9421.

42. Cortés-Eslava J, Gómez-Arroyo S, Villalobos-Pietrini R, Espinosa-Aguirre JJ: Antimutagenicity of coriander (Coriandrum sativum) juice on the mutagenesis produced by plant metabolites of aromatic amines. Toxicol Lett 2004, 153:283-292.

43. Robbins RJ: Phenolic acids in foods: an overview of analytical methodology. J Agr Food Chem 2003, 51:2866-2887.

44. Ng LK, Lafontaine P, Harnois J: Gas chromatographic-mass spectrometric analysis of acids and phenols in distilled alcohol beverages: application of anion-exchange disk extraction combined with in-vial elution and silylation. J Chromatogr A 2000, 873:29-38.

45. Dias MI, Barros L, Sousa MJ, Ferreira IC: Comparative study of lipophilic and hydrophilic antioxidants from in vivo and in vitro grown Coriandrum sativum. Plant Food Hum Nutr 2011, 66:181-186.

46. Taniguchi M, Yanai M, Xiao YQ, Kido T-i, Baba K: Three isocoumarins from Coriandrum sativum. Phytochemistry 1996, 42:843-846.

47. Esiyok D, Otles S, Akcicek E: Herbs as a food source in Turkey. Asian Pac Cancer $P$ 2004, 5:334-339.

48. Lei J, Yu J, Yu H, Liao Z: Composition, cytotoxicity and antimicrobial activity of essential oil from Dictamnus dasycarpus. Food Chem 2008 107:1205-1209.

49. Pandey A, Bigoniya P, Raj V, Patel K: Pharmacological screening of Coriandrum sativum Linn. for hepatoprotective activity. J Pharm Bioallied Sci 2011, 3:435.

50. Chung I-M, Ahmad A, Kim S-J, Naik PM, Nagella P: Composition of the essentia oil constituents from leaves and stems of Korean Coriandrum sativum and their immunotoxicity activity on the Aedes aegypti L. Immunopharm Immunot 2012, 34:152-156.

51. Putchala MC, Ramani P, Sherlin HJ, Premkumar P, Natesan A: Ascorbic acid and its pro-oxidant activity as a therapy for tumours of oral cavity-a systematic review. Arch Oral Biol 2013, 58:563-574

52. Kurbacher CM, Wagner U, Kolster B, Andreotti PE, Krebs D, Bruckner HW: Ascorbic acid (vitamin C) improves the antineoplastic activity of doxorubicin, cisplatin, and paclitaxel in human breast carcinoma cells in vitro. Cancer Lett 1996, 103:183-189.

53. Osmak M, Kovacek I, Ljubenkov I, Spaventi R, Eckert-Maksic M: Ascorbic acid and 6-deoxy-6-chloro-ascorbic acid: potential anticancer drugs. Neoplasma 1997, 44:101-108

54. Chen Q, Espey MG, Krishna MC, Mitchell JB, Corpe CP, Buettner GR, Shacter E, Levine M: Pharmacologic ascorbic acid concentrations selectively kill cancer cells: action as a pro-drug to deliver hydrogen peroxide to tissues. Proc Natl Acad Sci USA 2005, 102:13604-13609.

55. Matés JM, Sánchez-Jiménez FM: Role of reactive oxygen species in apoptosis: implications for cancer therapy. Int J Biochem Cell B 2000, 32:157-170.

56. Bijur GN, Briggs B, Hitchcock CL, Williams MV: Ascorbic aciddehydroascorbate induces cell cycle arrest at G2/M DNA damage checkpoint during oxidative stress. Environ Mol Mutagen 1999, 33:144-152.

57. Cha J, Roomi MW, Ivanov V, Kalinovsky T, Niedzwiecki A, Rath M: Ascorbate supplementation inhibits growth and metastasis of B16FO melanoma and 4 T1 breast cancer cells in vitamin C-deficient mice. Int J Oncol 2013, 42:55.

doi:10.1186/1472-6882-13-347

Cite this article as: Tang et al:: Antioxidant activity of Coriandrum sativum and protection against DNA damage and cancer cell migration. BMC Complementary and Alternative Medicine 2013 13:347. 